\title{
Hyaloideocapsular ligament of Wieger and vitreous loss in the course of intracapsular lens extraction
}

\author{
ALY MORTADA \\ Department of Ophthalmology, Faculty of Medicine, Cairo University
}

With modern surgery the incidence of vitreous loss should not be higher than 3 per cent $\frac{\Omega}{0}$. (Vail, I955; Müller, I966; Kettesy, I967). The surgeon fears vitreous loss because it may give rise to such complications as astigmatism, secondary glaucoma, drawn-up. pupil, retinal detachment, bullous keratopathy, corneal opacities, oedema of the optic. disc and macula, or iridocyclitis which may progress to shrinkage of the globe. Statistics show that approximately 6 per cent. of such eyes are lost within a year and usually within음 2 months. Of the remainder, 18 per cent. have no useful vision after a year and only 20 per cent. have vision better than $6 / 18$ after 3 years; after 3 years, however, the chanceso of retaining this vision are high (Vail, I 965 ).

\section{Present investigations}

To discover the cause of vitreous loss after the use of modern preoperative measures ato modern surgery, 200 intracapsular lens extractions for immature and mature catara were reviewed.

\section{Methods}

Preoperatively several precautionary measures were taken to prevent loss of vitreous during the operation:

(1) There was no straining as in coughing.

(2) The instruments were of the best type.

(3) There was no pressure on the globe.

(4) Anaesthesia, including facial akinesia, was perfect.

(5) A retrobulbar injection was given for extraocular muscle paralysis.

(6) Hypotensive agents such as acetazolamide were used before operation, with hypotensive osmotic therapy such as oral glycerine, and a purgative, combined with digital pressure on the globeo (Atkinson, 1955).

(7) Use of a Flieringa-Bonaccolto ring if there was a tendency to scleral collapse.

(8) The use of analgesics, hypnotics, tranquilizers, sedatives, and antihistaminics up to the level $\mathbb{\mathscr { O }}$ of toleration in each patient to induce calm and prevent engorgement of the uveal vessels, especially choroidal vessels.

\section{Technique}

Lens extraction was performed by the multiple methods technique (Mortada, 1963, I965). $A$ von Graefe knife section was made at the corneal side of the limbus with a very small conjunctival 
flap, cutting up from I mm. above the horizontal corneal meridian on either side. A key-hole iridectomy was performed, and three conjunctivo-corneosclero-conjunctival virgin silk sutures were placed at the 10, 12, and 2 o'clock meridians but not tied. The extraction began by external pressure zonulotomy (not that used by Smith, 1926). Pressure was applied with the tip of the strabismus hook moved on the sclera along the lower $180^{\circ}$ arc, 2 to $3 \mathrm{~mm}$. from the limbus without counter pressure. The aim of this pressure was to make a small scleral identation, giving a shelf aiming at raising the lower pole of the lens, thus separating the lower zonular fibres and lower part of the hyalocapsular ligament and subluxating the lens from below.

Inspite of this special lower external pressure aimed at tumbling the lens, the lens subluxated from below in 35 per cent. of cases. In 60 per cent. the lens presented in the wound with its upper pole first and in 5 per cent. it appeared to be reluctant to leave the eye after 3 minutes of lower external pressure.

Once the lens was subluxated the lens capsule was held by the non-toothed capsule-forceps just anterior to the equator from side of the subluxated lens. In cases of lower subluxation the extraction was continued by tumbling (Arruga, 1933). If the lens subluxated from above or had no tendency to leave the eye, the extraction was continued by the head-first technique described by Kirby (1938).

The operation was concluded by tying the three corneoscleral sutures, reposition of iris pillars, air injection into the anterior chamber, and reposition of the conjunctival flap.

\section{Results}

(A) In 35 per cent. of cases in which the lens subluxated firstly from below and extraction was by tumbling, there was no vitreous loss.

(B) In 60 per cent. of cases in which the lens subluxated firstly from above and extraction was by the upper pole first delivery technique, there were four cases of vitreous loss.

(i) As the lens was raised from above, in six cases the hyaloid separated from its attachment to the ora serrata in the upper part of the globe and the vitreous bulged out between the lens and the scleral lip of the wound. In four cases the vitreous was replaced by the back of the lens and in two other cases, as delivery continued and because of the adherent hyalocapsular attachment, the exposed bulging vitreous face ruptured causing vitreous loss.

(ii) As the lens was raised from above, in two cases of myopic eyes, the anterior hyaloid face was found to be degenerated with fluid vitreous seeping out during the extraction.

(C) In 5 per cent. of cases where the lens showed no inclination to leave the eye, the extraction was continued by the upper pole first delivery technique, and because of the adherent hyalocapsular ligament in four cases, the hyaloid membrane was partly detached with the adherent posterior lens capsule, which led to vitreous loss.

It is known that neither alpha-chymotrypsin nor cryoextraction has any effect on the ease of separation of the hyalocapsular ligament.

\section{Discussion}

To know the degree of attachment of the hyaloid membrane to the ora serrata, posterior lens capsule, and zonule is of great importance during intracapsular lens extraction.

The hyaloid membrane, the condensation of the vitreous face (Duke-Elder, 1930; Hilding, I954), is firmly attached in a ring 2 to $3 \mathrm{~mm}$. wide which extends forwards from the ora serrata to the pars plana of the ciliary body.

The vitreous adheres to the posterior surface of the lens by the hyalocapsular ligament (Wieger, 1883 ), which forms a ring 8 to $9 \mathrm{~mm}$. in diameter $\mathrm{I} \mathrm{mm}$. from the periphery of the 
lens. Elsewhere in the patellar fossa, the vitreous is separated from the lens by the cap? illary space of Berger ( $188_{3}$ ), which sometimes contains aqueous (Duke-Elder and Wybar I96 I ). In the course of intracapsular extraction the ligament slowly peels away from the patellar fossa stage by stage (Vail, 1937). An adhesion of the hyaloid layer of the vitreous to the capsule of the lens, which is usually associated with a persistent hyaloid artery, $\overrightarrow{\overrightarrow{\vec{\phi}}}$ condition relatively common in early life, may result in serious vitreous loss during a intracapsular extraction (Vail, I954; Wolter, I96 I ).

Some zonular fibres of Zinn may be firmly and intimately associated with the vitreous at their point of origin, and this is important if the vitreous is disturbed by the intra capsular method of lens extraction (Vail, 1952). This attachment has been called the hyalozonular ligament (Minsky. I942).

\section{Summary}

(I) With modern preoperative precautions and operative techniques vitreous loss occurre in 4 per cent. of 200 intracapsular lens extractions for senile cataract.

(2) The main cause of vitreous loss was the effort required to separate a closely adherent hyalocapsular ligament.

(3) Neither alpha-chymotrypsin (Barraquer, 1958) nor the cryo probe (Krwawicz? I96 I) makes the separation of the hyalocapsular ligament any easier or safer.

(4) In the multiple methods technique of cataract extraction (i.e. using tumbling of upper pole first extraction according to the site of lens subluxation noted after using $\bar{z}$ specially designed method of external pressure for mechanical zonulotomy (Mortada霖

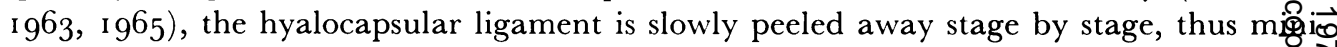
mizing the risk of vitreous loss.

\section{References}

AtKinson, w. s. (1955) “Anaesthesia in Ophthalmology". Thomas, Springfield, Ill.

ARRUGA, H. (1933) Bull. Soc. franç. ophtal., 46, 270

BERGER, E. (1883) Morphol. Jb., 8, 97

BarraQuer, J. (1958) Acta ophthal. (Kbh), 36, 803

DUKe-ELder, s. (1930) Brit. J. Ophthal., Suppl. 4 and WYBAR, K. c. (196I ) "System of Ophthalmology", vol. 2, p, 295. Kimpton, Londo

hilding, A. C. (1954) A.M.A. Arch. Ophthal., 52, 497

KetTesy, A. (1967) Klin. Mbl. Augenheilk., 150, 785

кIRBy, D. в. (1938) Amer. F. Ophthal., 19, 1006

KRWAWicz, T. (1961) Brit. F. Ophthal., 45, 279

Minsky, H. (1942) Arch. Ophthal. (Chicago), 28, 2 I 4

mORTADA, A. (1963) Brit. 7. Ophthal., 47, 753 (1965) Bull. ophthal. Soc. Egypt, 58, 339

Müller, н. (1966) Wiss. Z. Ernst-Moritz-Arndt-Univ. Greifswald Math.-nat. Reihe, 15, 507

sмiтн, н. (1926) Arch. Ophthal. (N.Y.), 55, 213

vaIL, D. (1952) A.M.A. Arch. Ophthal., 48, 405

- (1954) Trans. Amer. Acad. Ophthal. Otolaryng., 58, 367

(1957) Trans. ophthal. Soc. U.K., 77, $44^{1}$

(1965) Amer. F. Ophthal., 59, 573

wieger, G. (1883) “Ueber den Canalis Petiti und ein "Ligamentum hyaloideo-capsulare". Heit

Strassburg

WOLter, J. R. (196I) Amer. F. Ophthal., 5I, 5II 